\title{
Characterization of a Dual-Specificity Protein Phosphatase, Human DUSP28
}

\author{
Dae Gwin Jeong ${ }^{2}$, Song Yi Kim², Jeong Hun Yun ${ }^{1,3}$ and Jae Hoon Kim ${ }^{1,3}$ * \\ ${ }^{1}$ Faculty of Biotechnology, College of Applied Life Science, Jgiu National University, Jeju 690-756, Korea \\ ${ }^{2}$ Medical Genomics Research Center, Korea Research Institute of Bioscience and Biotechnology, Dageon 305-806, Korea \\ ${ }^{3}$ Citrus Genetic Resources Bank, Joju National University, Jgiu 690-756, Korea
}

Received November 10, 2010 /Accepted December 7, 2010

\begin{abstract}
Dual-specificity protein phosphatases (DUSPs) constitute a family of protein phosphatase characterized by the ability to dephosphorylate phospho-tyrosyl and phospho-seryl/threonyl residues. Most DUSPs are involved in regulation of cell survival and differentiation. In this study, a human dual-specificity protein phosphatase, DUSP28, was isolated from a human kidney cDNA. The recombinant protein was successfully produed in E.coli and showed sufficient phosphatase activity toward DiFMUP (6,8-difluoro-4-methylumbelliferyl phosphate). Various phosphatase inhibitors and divalent metals were tested for their effects on the DUSP28 phosphatase activity. As a result, $\mathrm{Zn}^{2+}$ was found to strongly inhibit DUSP28 phosphatase activity, suggesting DUSP28 is involved in Zn-related signal transduction pathway. Furthermore, the DUSP28 protein preferred phospho-tyrosyl residues to phospho-threonyl residues, implying its physiological roles in the cellular process.
\end{abstract}

Key words : Dual-specificity protein phosphatase 28, recombinant protein, 6,8-difluoro-4-methylumbelliferyl phosphate, phosphatase activity, inhibitors

Introduction

A family of dual-specificity protein phosphatases (DUSPs) catalyzes dephosphorylation of protein substrates at both tyrosine and threonine residues [1], and regulates the phosphorylation levels of proteins that play crucial regulatory roles in cellular signal transduction mediating cell survival, proliferation, and differentiation [16]. To date, 24 human DUSPs have been registered to GeneBank at National Center for Biotechnology Information U.S (NCBI). Of these DUSPs, the subgroup of typical MAP kinase phosphatase (MKPs) has a catalytic domain and an additional MAP kinase binding (MKB) domain [6]. Another subgroup of DUSPs is distinct from the typical DUSPs in that they lack the MKB domain, resulting in small-sized phosphatases. The prototypical mammalian atypical DUSP is DUSP3/VHR that is implicated in the control of MAP kinase signaling pathways [15]. All of human DUSPs contain a signature motif, HCXXGXXR, except DUSP28 (NCBI accession number, NP_001028747) in which the conserved histidine is changed to tyrosine. In case of DUSP3/VHR, the conserved histidine residue appeared to interact with the carbonyl group of the active-site cysteine residue by a hydrogen bond [19]. Some

*Corresponding author

Tel : +82-64-754-3358, Fax : +82-64-756-3351

E-mail : kimjh@jejunu.ac.kr mutations of the conserved histidine decreased $K_{\text {cat }}$ about 10 -fold in VHR, demonstrating the hydrogen bonding of histidine is crucial for maintain the proper positioning of the active-site cysteine in the catalytic site [8]. Recently, studies of gene expression profile showed that DUSP28 was down-regulated in immune cells and activated in the transcript factor CHF1/Hey2 transgenic myocytes, respectively $[2,18]$. Even though DUSP28 has a unique aspect, no functional studies for phosphatase activity and substrates had been reported. Here, we report the expression and characterization of the human DUSP28 gene.

\section{Materials and Methods}

\section{Cloning, expression and purification of DUSP28}

The full-length DUSP28 gene was amplified by PCR using the human kidney cDNA (Clontech, Mountain View, CA) with DUSP28-specific primers, [DUSP28F; 5'-GCGCGCA TATGGGCACCTCGGAGGCTGCACCG-3' and DUSP28R; 5'-GCGCGGATCCTTACTCCGGATCAATGGGCTCCCG-3']. Two primers are designed to have a sequence (underlined) of $5^{\prime}$ region or $3^{\prime}$ region of a full-length DUSP28, respectively. The amplified PCR product was subcloned into the $N d d-B a m H$ site of the pET28a $(+)$ vector (Novagen, Darmstad,Germany), resulting in the N-terminal His-tagged protein. The DUSP28-C103S mutant protein, containing a 
cysteine-to-serine alteration at position 103, was generated using oligonucleotide primers and was confirmed by DNA sequencing analysis. E.coli BL21(DE3) cells harboring the DUSP28 gene were grown at $18^{\circ} \mathrm{C}$, and the protein expression was induced with $0.1 \mathrm{mM}$ IPTG for $16 \mathrm{hr}$. The cell lysate was prepared by sonication with a buffer containing $50 \mathrm{mM}$ Tris- $\mathrm{HCl}, \mathrm{pH} 7.5,200 \mathrm{mM} \mathrm{NaCl}, 0.5 \mathrm{mM}$ PMSF, $0.04 \%(\mathrm{v} / \mathrm{v})$ 2-mercaptoethanol. The His-tagged DUSP28 protein was purified by nickel-affinity chromatography.

\section{Phosphatase assay}

To analyze the phosphatase activity, DiFMUP (6,8-difluoro-4-methylumbelliferyl phosphate, Molecular probe_D6567), was used as a substrate. The purified recombinant DUSP28 protein was assayed for phosphatase activity using $5 \mu \mathrm{m}$ DiFMUP (6,8-difluoro-4-methylumbelliferyl phosphate, Molecular probe_D6567). The reaction was performed at $25^{\circ} \mathrm{C}$ for $30 \mathrm{~min}$, and then stopped by adding sodium vanadate (final concentration $2 \mathrm{mM}$ ). Reaction product, DiFMU, exhibits excitation/emission maxima of 358/452 nm. Absorbance was measured with a Wallac Victor ${ }^{2} 1420$ multilabel counter (PerkinElmer Wellesley, MA). The pH dependence of DUSP28 was determined by incubating the reaction mixture at various $\mathrm{pH}$ buffers $(20 \mathrm{mM}$ sodium citrate $\mathrm{pH}$ 4.5, sodium citrate $\mathrm{pH}$ 5.0, Bis-tris $\mathrm{pH} 5.5$, MES $\mathrm{pH}$ 6.0, MES $\mathrm{pH}$ 6.5, Hepes- $\mathrm{NaOH}$ pH 7.0, Hepes-NaOH pH 7.5, Tris- $\mathrm{HCl}$ $\mathrm{pH}$ 8.0, Tris- $\mathrm{HCl} \mathrm{pH} 8.5$, BICIN pH 9.0). For determination of the effects of phosphatase inhibitors, $5.4 \mu \mathrm{M}$ of DUSP28 was incubated with DiFMUP in the absence or presence of $1 \mathrm{mM}$ sodium orthovanadate, PMD (pentamidine), and $\mathrm{NaF}$. The effects of cations on the phosphatase activity were tested in the presence of $1 \mathrm{mM}$ each of divalent metal ions.

\section{Substrate specificity phosphatase assay}

The tyrosine phosphatase assay system and serine/threonine phosphatase assay system (Promega) were used to determine the substrate specificity of DUSP28. The reaction mixtures contained $10 \mu \mathrm{l}$ of $100 \mathrm{mM}$ Hepes, $\mathrm{pH}$ 6.0, $5 \mu \mathrm{l}$ phosphopeptide ( $1 \mathrm{mM}$, provided by the assay system) and different concentrations of DUSP28 in a total of $50 \mu l$. The reactions were performed at $37^{\circ} \mathrm{C}$ for $45 \mathrm{~min}$ and stopped by adding $50 \mu \mathrm{l}$ of molybdate dye-additive mixture (provided by the assay system). The standard curve was made according to the manufacturer protocol. The released phosphate was monitored by measuring the absorbance at $600 \mathrm{~nm}$ on Model 450 Microplate Reader (Bio-Rad). The phosphopeptide sequences were Tyr phosphopeptide-1 (END(pY)INASL), Tyr phosphopeptide-2 (DADW(pY)LIPQQG) and Thr phosphopeptide (RRA(pT)VA).

\section{Results and Discussion}

The DUSP 28 gene encodes a 176 residues protein that has a dual-specificity protein catalytic (DSPc) domain from residue 18 to 153 . The full-length DUSP28 gene was expressed in E. coli cells and its product was purified by nickel-affinity chromatography (Fig. 1).

The phosphatase activities of DUSP28-WT and DUSP28-CS mutants toward DiFMUP were first examined. The wild type DUSP28 (DUSP28-WT) protein showed phosphatase activity in a dose-dependent manner (Fig. 2A). However, The DUSP28-CS mutant protein in which the active-site cysteine 103 was substituted with serine had little phosphatase activity, showing that cysteine 103 is important for phosphatase activity. To find out the optimum $\mathrm{pH}$ at which DUSP28 would best break down DiFMUP, we assayed the phosphatase activity at various $\mathrm{pH}$ values. The optimal pH for the enzymatic activity was pH 6.0 (Fig. 2B).

Next we investigated the inhibition of phosphatase activity with various phosphatase inhibitor compounds. The phosphatase activity of DUSP28 was strongly inhibited by sodium orthovanadate, which is a specific inhibitor of Tyr phosphatases (Fig. 3A). Sodium fluoride (NaF), a commonly used general inhibitor for Ser/Thr phosphatase, inhibited DUSP 28 phosphatase activity about 10\%. Pentamidine (PMD), which is known as an inhibitor of PRL phosphatase, showed about $22 \%$ inhibition of phosphatase activity. Then, DUSP28 phosphatase was examined in terms of divalent

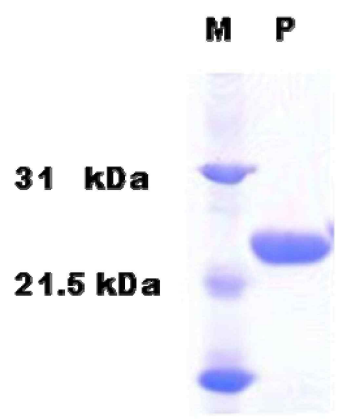

Fig. 1. Expression and purification of DUSP28. DUSP28 was expressed in E.coli BL21 (DE3) and purified by chromatography. The purified protein $(2 \mu \mathrm{g})$ was analyzed by SDS-PAGE. Positions of the molecular mass markers $(\mathrm{kDa})$ are shown on the left. 
(A)

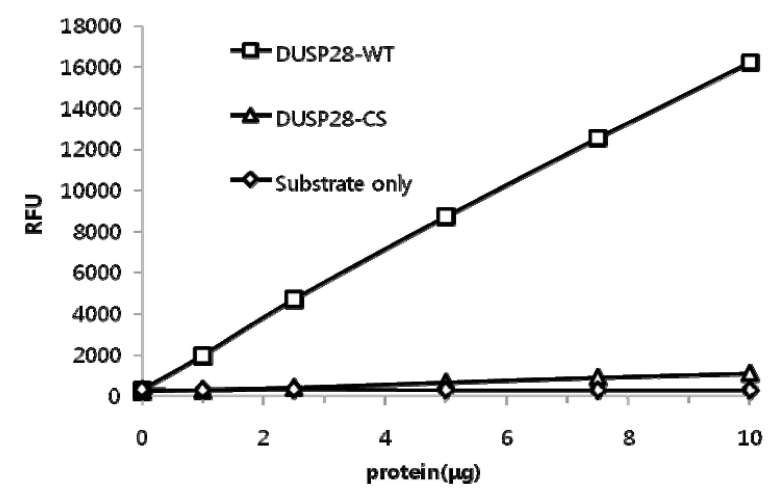

(B)

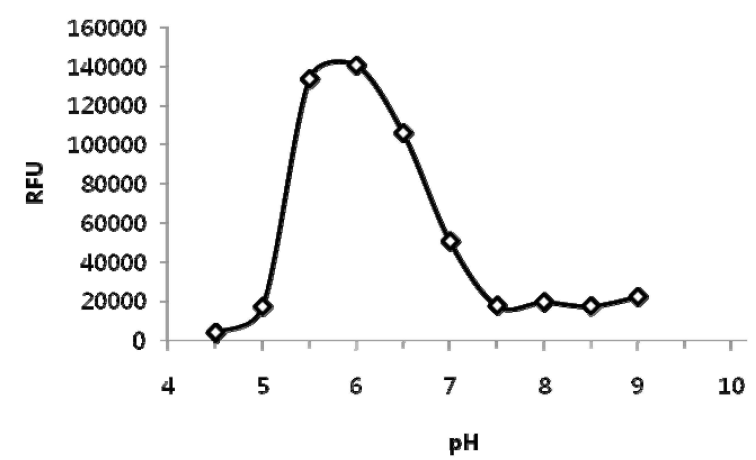

Fig. 2. Enzyamtic properties of DUSP28. Purified recombinant DUSP28-WT and DUSP28-CS (C103S) were assayed for phosphatase activity using $5 \mu \mathrm{M}$ DiFMUP as a substrate. Relative fluorescence unit (RFU) of the reaction product, DiFMUP, was measured. The RFU correlates to the relative quantity of DiFMU in the sample based on its response from the detector (A). Effect of $\mathrm{pH}$ on the activity of DUSP28. Reaction mixtures containing $5 \mu \mathrm{M}$ DiFMUP and $5.4 \mu \mathrm{M}$ DUSP28 were incubated at various $\mathrm{pH}$ buffer (20 mM sodium citrate $\mathrm{pH} 4.5$, sodium citrate $\mathrm{pH} 5.0$, Bis-tris pH 5.5, MES pH 6.0, MES pH 6.5, Hepes-NaOH $\mathrm{pH}$ 7.0, Hepes- $\mathrm{NaOH}$ pH 7.5, Tris- $\mathrm{HCl} \mathrm{pH}$ 8.0, Tris- $\mathrm{HCl}$ $\mathrm{pH} 8.5$, BICIN pH 9.0) (B). The values are shown as mean of three independent assays.

metal ion effects on DUSP28 activity. Although DUSP28 did not contain any known metal binding motif, $2 \mathrm{mM}$ of $\mathrm{Zn}^{2+}$ greatly inhibited the phosphatase activity. $\mathrm{Co}^{2+}$ also caused a meaningful decrease of the activity. On the other hand, phosphatase activity was slightly higher in the presence of $2 \mathrm{mM} \mathrm{Mg}^{2+}$ and $\mathrm{Ca}^{2+}$, respectively. $\mathrm{Mn}^{2+}$ did not show any effect (Fig. 3B). In fact, $\mathrm{Zn}^{2+}$ was reported to inhibit $\mathrm{T}$ cell protein tyrosine phosphatase possibly through the binding to the cysteine residue at the catalytic site [13]. However, the presence of a cysteine residue at the catalytic site seems to be not sufficient to provide an inhibitory site, because the active site of enzymes may be designed to be protected
(A)

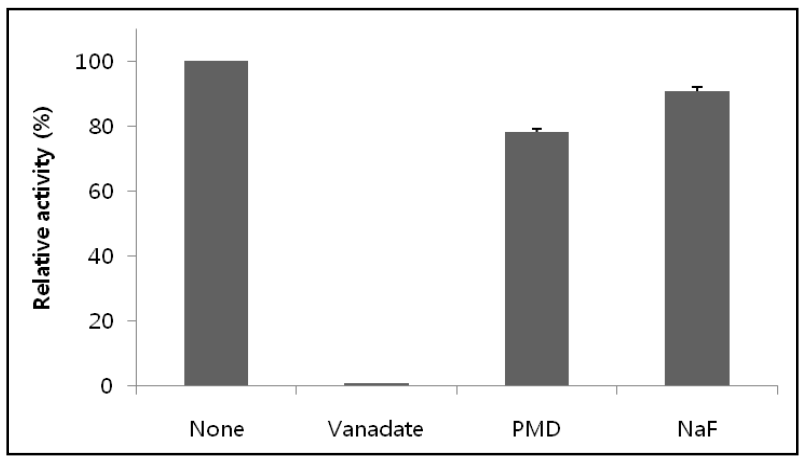

(B)

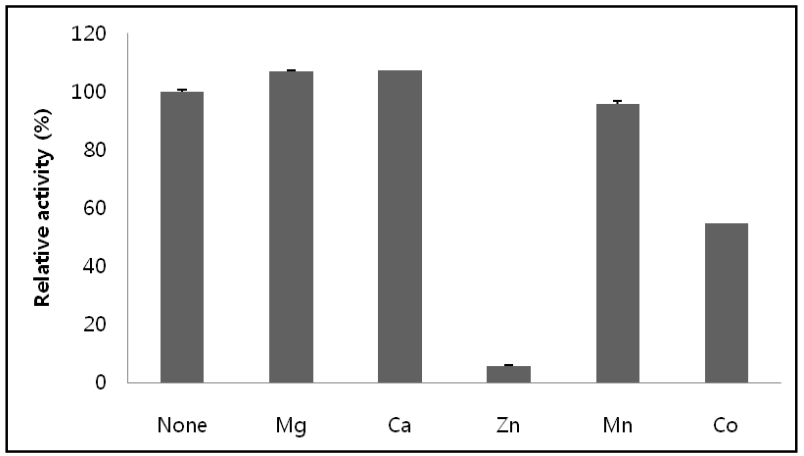

Fig. 3. Effects of phosphatase inhibitors on DUSP28 activity. Several known phosphatase inhibitors were tested for their effect on the ability of DUSP28 to dephosphorylate DiFMUP. $5.4 \mu \mathrm{M}$ of DUSP28 was incubated with DiFMUP in the absence or presence of $1 \mathrm{mM}$ sodium orthovanadate, PMD (pentamidine), NaF (A). Effects of divalent ion on DUSP28 activity. The reaction samples were incubated in the presence of $2 \mathrm{mM}$ each of the divalent metal ions (B). The values are shown as mean \pm S.E. of three independent assays.

from inhibition by $\mathrm{Zn}^{2+}$. All DUSPs have an essential cysteine residue at the active site that might be the target of $\mathrm{Zn}^{2+}$ inhibition, but $\mathrm{Zn}^{2+}$ partially decreased some DUSPs such as LMW-DSP3 (DUSP19) [4] and DUSP3/VHR [9]. In this study, $\mathrm{Zn}^{2+}$ was found to inhibit about $95 \%$ of DUSP28 phosphatase activity, suggesting DUSP28 might be involved in Zinc-regulated signal pathway. Zinc in the ambient air was proved to be strongly associated with the prevalence of asthma [5], and animal studies were shown that the inhalation of zinc induces adverse pulmonary health effects [7,12]. Zinc exposure was reported to induce the phosphorylation of mitogen-activated protein kinases that are cellular substrates of DUSPs by inhibiting a functionally undefined DUSP activity in human airway epithelial cells [11].

Although DUSPs are known to dephosphorylate protein 
at both tyrosine and threonine residues, some of them have a preference for their substrates. For example, DUSP3/VHR prefers phosphor-tyrosine (pY) to phosphor-threonine (pT) in the dephosphorylation reactions [19], whereas DUSP13/ TMDP has a similar activity toward both pY and pT [14]. To determine the substrate specificity, three phospho-peptides such as Tyr phosphopeptide-1 (END(pY)INASL), Tyr phosphopeptide-2 (DADW(pY)LIPQQG) and Thr phosphopeptide (RRA(pT)VA) were used in phosphatase activity assay. The recombinant DUSP28 dephosphorylate both Tyr phosphopeptide-1 and Tyr phosphopeptide-2, depending on the amounts of enzymes of enzyme added up to $8 \mu \mathrm{g}$ (Fig. 4). The specific activity of DUSP28 towards Tyr phosphopeptide-2 was $4.3 \mathrm{pmol} / \mathrm{min}$ per $\mu \mathrm{g}$, which is higher than that (3.1 $\mathrm{pmol} / \mathrm{min}$ per $\mathrm{ug}$ ) toward Tyr phosphopeptide-1. However, DUSP28 did not show any significant activity toward Thr phosphopeptide that was a good substrate for DUSP19 and DUSP23 (Fig. 3) [4,17]. These results demonstrate that DUSP 28 prefers $\mathrm{pY}$ to $\mathrm{pT}$, similar to DUSP3/VHR. The structure and charges of active region are mainly responsible for the substrate specificity.

DUSP3/VHR has a relatively deep active site pocket that is easily accessible only by $\mathrm{pY}$, whereas DUSP13/TMDP has a wider and more planner active pocket than DUSP3/VHR [10]. In phylogenetic dendrogram suggested by carols et.al,

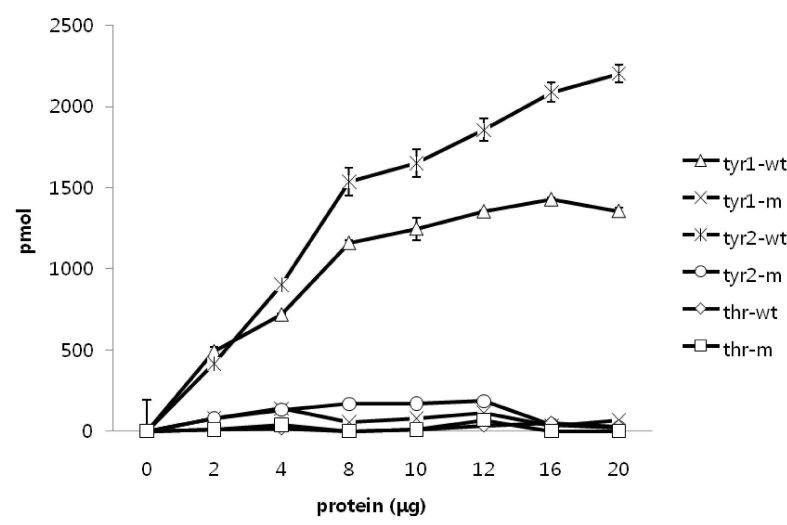

Fig. 4. Substrate specificity of DUSP28. $0.1 \mathrm{mM}$ each of tyr1 (END(pY)INASL), tyr2 (DADW(pY)LIPQQG), and thr $(\mathrm{RRA}(\mathrm{pT}) \mathrm{VA})$ were used as substrates. Indicated amounts of DUSP28 were assayed (tyr1-wt: tyr1 plus DUSP28 wild-type protein; tyr1-m; tyr1 plus DUSP28 (C103S) mutant protein; tyr2-wt: tyr2 plus DUSP28 wild-type protein; tyr2-m; tyr2 plus DUSP28 (C103S) mutant protein; thr-wt: thr plus DUSP28 wild-type protein; thr-m; thr plus DUSP28 (C103S) mutant protein). The values are shown as mean \pm S.E. of three independent assays.
DUSP3/VHR and DUSP13/TMDP are involved in atypical DSP-IA subfamily and DUSP28 is a member of another DSP-II subfamily [3]. These results suggest that, in spite of different evolutionary origins, the active site structure and physiological substrate of DUSP28 might be similar to DUSP3/VHR.

In conclusion, human DUSP28 was cloned and expressed as an active form in E.coli. Different from other reported DUSPs, DUSP28 was strongly inhibited by zinc and preferred pY to pT. Our results suggest that DUSP28 can be a candidate phosphatase to play a role in Zn-related signaling in cellular physiological process. Further research will identify the cellular substrate and function of DUSP28 in vivo.

\section{Acknowledgment}

This work was supported by the Korea Research Foundation Grant funded by the Korean Government (MOEHRD, Basic Research Promotion Fund) (KRF-3132007-2-C00461).

\section{References}

1. Alonso, A., J. Sasin, N. Bottini, I. Friedberg, A. Osterman, A. Godzik, T. Hunter, J. Dixon, and T. Mustelin. 2004. Protein tyrosine phosphatases in the human genome. Cell 117, 699-711.

2. Arimura, Y. and J. Yagi. 2010. Comprehensive expression profiles of genes for protein tyrosine phosphatases in immune cells. Sci. Signal. 3, 11-18.

3. Carlos, R. M., R. Pablo, T. Lydia, K. A. Teresa, and P. Rafael. A novel phosphatase family, structurally related to dual-specificity phosphatases, that displays unique amino Acid Sequence and Substrate Specificity. J. Mol. Biol. 374, 899-909.

4. Cheng, H., Q. Gao, M. Jiang, Y. Ma, X. Ni, L. Guo, W. Jin, G. Cao, C. Ji, K. Ying, W. Xu, S. Gu, Y. Ma, Y. Xie, and Y. Mao. 2003. Molecular cloning and characterization of a novel human protein phosphatase, LMW-DSP3. Int. J. Biochem Cell Biol. 35, 226-234.

5. Claiborn, C. S., T. Larson, and L. Sheppard. 2002. Testing the metals hypothesis in Spokane, Washington. Environ. Health Perspect 110, 547-552.

6. Farooq, A. and M. M. Zhou. 2004. Structure and regulation of MAPK phosphatases. Cellular Signal 16, 769-779.

7. Gordon, T., L. C. Chen, J. M. Fine, R. B. Schlesinger, W. Y. Su, T. A. Kimmel, and M. O. Amdur. 1992. Pulmonary effects of inhaled zinc oxide in human subjects, guinea pigs, rats, and rabbits. Am Ind Hyg. Assoc. J. 53, 503-509.

8. Kim, J. H., D. Y. Shin, M. H. Han, and M. U. Choi. 2001. Mutational and kinetic evaluation of conserved His-123 in 
dual specificity protein-tyrosine phosphatase vaccinia H1-related phosphatase: participation of Tyr-78 and Thr-73 residues in tuning the orientation of His-123. J. Biol. Chem 276, 27568-27574.

9. Kim, J. H., H. Cho, S. E. Ryu, and M. U. Choi. 2000. Effects of metal ions on the activity of protein tyrosine phosphatase VHR: highly potent and reversible oxidative inactivation by $\mathrm{Cu}^{2+}$ ion. Arch. Biochem Biophys. 382, 72-80.

10. Kim, S. J., D. G. Jeong, T. S. Yoon, J. H. Son, S. Kim Cho, S. E. Ryu, and J. H. Kim. 2007. Crystal structure of human TMDP, a testis-specific dual specificity protein phosphatase: implications for substrate specificity. Proteins 66, 239-245.

11. Kim, Y. M., W. Reed, W. Wu, P. A. Bromberg, L. M. Graves, and J. M. Samet. 2006. Zn2 ${ }^{+}$-induced IL-8 expression involves AP-1, JNK, and ERK activities in human airway epithelial cells. Am J. Physiol. Lung Cell Mol. Physiol. 290, 1028-1035.

12. Kodavanti, U. P., M. C. Schladweiler, A. D. Ledbetter, R. Hauser, D. C. Christiani, J. M. Samet, J. McGee, J. H. Richards, and D. L. Costa. 2002. Pulmonary and systemic effects of zinc-containing emission particles in three rat strains: multiple exposure scenarios. Toxicol. Sci. 70, 73-85.

13. Maret, W., C. Jacob, B. L. Vallee, and E. H. Fischer. 1999. Inhibitory sites in enzymes: zinc removal and reactivation by thionein. Proc. Natl. Acad Sci. U.S.A. 96, 1936-1940.
14. Nakamura, K., H. Shima, M. Watanabe, T. Haneji, and K. Kikuchi. 1999. Molecular cloning and characterization of a novel dual-specificity protein phosphatase possibly involved in spermatogenesis. Biochem J. 344, 41404-41413.

15. Todd, J. L., K. G. Tanner, and J. M. Denu. 1999. Extracellular regulated kinases (ERK) 1 and ERK2 are authentic substrates for the dual-specificity protein-tyrosine phosphatase VHR. A novel role in down-regulating the ERK pathway. J. Biol. Chem 274, 13271-13280.

16. Treisman, R. 1996. Regulation of transcription by MAP kinase cascades. Curr. Opin. Cell Biol. 8, 205-215.

17. Wu, Q., Y. Li, S. Gu, N. Li, D. Zheng, D. Li, Z. Zheng, C. Ji, Y. Xie, and Y. Mao. 2004. Molecular cloning and characterization of a novel dual-specificity phosphatase 23 gene from human fetal brain. Int. J. Biochem Cell Biol. 36, 154-1553.

18. Yu, M., F. Xiang, R. P. Beyer, F. M. Farin, T. K. Bammler, and M. T. Chin. 2010. Transcription Factor CHF1/Hey2 Regulates Specific Pathways in Serum Stimulated Primary Cardiac Myocytes: Implications for Cardiac Hypertrophy. Current Genomics 11, 287-296.

19. Yuvaniyama, J., J. M. Denu, J. E. Dixon, and M. A. Saper. 1996. Crystal structure of the dual specificity protein phosphatase VHR. Science 272, 1328-1331.

\section{초록 : 인간유래의 dual-specificity protein phosphatase, DUSP28의 활성분석}

정대균 $^{2} \cdot$ 김송이 $^{2} \cdot$ 윤정훈 ${ }^{13} \cdot$ 김재훈,3*

( ${ }^{1}$ 제주대학교 생명공학부, ${ }^{2}$ 한국생명공학연구원 단백체의학연구센터, ${ }^{3}$ 제주대학교 감귤유전자원소재은행)

Dual-specificity protein phosphatase (DUSP)들은 인산화된 티로신 잔기와 인산화된 세린 또는 트레오닌 잔기 를 탈인산화시키는 단백질 탈인산화효소 군을 이루고 있으며, 대부분의 DUSP들은 세포의 생존이나 분화에 관여 하고 있다. 본 연구에서는 잘 알려지지 않은 인간 유래의 dual-specificity protein phosphatase인 DUSP28을 인간 신장 cDNA에서 분리하였다. 대장균에서 생산된 재조합단백질은 6,8-difluoro-4-methylumbelliferyl phosphate (DiFMUP)에 대하여 좋은 활성을 보였다. 다양한 저해제와 2가 금속이온들이 DUSP28의 활성에 미치는 영향을 조사하였다. 다른 DUSP들에서와는 다르게, $\mathrm{Zn}^{2+}$ 은 DUSP28의 탈인산화활성을 강하게 억제하였다. 이러한 결과 로부터 DUSP28이 Zn과 연관된 신호전달경로에 관여할 것으로 추정된다. 더욱이, DUSP28은 인산화된 티로신 잔기를 더욱 선호하는 경향이 있는 것으로 나타났고, 이는 세포 내에서도 비슷한 작용을 할 것으로 예상된다. 